\title{
Research on transformation and upgrading of Liuzhou fitness industry under the "Internet +" service platform
}

\author{
Yi $\mathrm{Xie}^{1}$, Shijun $\mathrm{Xu}^{2, *}$, and Yanping Yang ${ }^{3}$ \\ ${ }^{1}$ Academy of Arts and Cultural Communication, Guangxi University of Science and Technology, \\ Liuzhou China \\ ${ }^{2}$ Lushan College, Guangxi University of Science and Technology, Liuzhou China \\ ${ }^{3}$ English teaching and Research Office, Liuzhou Railway Vocational and Technical College, Liuzhou \\ China
}

\begin{abstract}
Under the current situation of prevention and control Corona Virus Disease 2019(COVID-19), the development of fitness industry in Liuzhou is analyzed, and the survival environment, management, coaches' quality and reasons for the closure of the club are analyzed. The results show that Liuzhou fitness market is greatly affected by the economic and social environment, and the seemingly prosperous fitness market has met with bottlenecks, and its operation is in danger. Taking "Internet+" as a new power engine, we should build a service platform of Liuzhou fitness alliance, strengthen the supply side reform such as management and coach quality, increase effective supply of high quality, and guide clubs to play their own advantages to develop differentiated competition, which is an effective way to promote the transformation and upgrading of traditional fitness industry.
\end{abstract}

\section{Introduction}

Liuzhou is an important industrial town with a long history. It is located in the southwest transportation hub and has typical characteristics of a medium-sized city. The research on its fitness industry plays a role as a specimen for other third tier cities. In the implementation of the strategy of "prospering the city through industry, opening up and strengthening the city", Liuzhou city is committed to creating "smart city" and "green city" business cards. The municipal government has continuously increased its investment in transportation, environmental protection, public leisure services and other livelihood projects, which provides a good foundation for the development of fitness industry ${ }^{[1]}$. Liuzhou fitness market rose in the 1990s, gradually attracting a large number of social capital to invest in the fitness industry, and formed a large-scale development around 2010, among which there are no lack of national chain stores such as Total Fitness, Dance Land, etc., which mostly show the shadow of the development concept of Guangzhou, Shenzhen, Shanghai and other developed cities. There are frequent crises in the fitness market, which

\footnotetext{
* Corresponding author: $\underline{627726050 @ \text { qq.com }}$
} 
are obviously affected by economic and social development in recent years in Liuzhou, Especially, COVID-19 affected the whole of China in early 2020, which brought a great blow to the leisure oriented fitness industry characterized by clustering. As the representative of fashion, to form a sustainable development of fitness industry, we must keep pace with the times and integrate advanced science and technology and management concepts. The development of the "Internet + " traditional industries can inject new impetus to economic development and is an important way to realize China dream ${ }^{[2]}$. The development of the Internet plus traditional fitness industry has injected new impetus to the development of Liuzhou's fitness market. It can rely on science and technology and big data support to drive the upgrading of traditional fitness industry and break through the "bottleneck" of Liuzhou fitness market demand saturation.

\section{General situation of Liuzhou fitness market}

\subsection{Club distribution and market environment}

At present, there are nearly 100 fitness clubs in Liuzhou urban area, covering all aspects of the urban area in various scales and types. There are more than 60 fitness clubs gathered in the downtown area. The service supply has met the market demand, and even "supply exceeds demand". For the city with millions of people, the huge flow of people and the improvement of citizens' fitness demand continue to attract the enthusiasm of the society for investment in the fitness industry, and the fitness market segment has great potential for development. For example, in recent years, the small gym - fitness studio is gradually favored by consumers. Different from the traditional gymnasium characterized by "large and complete", the fitness studio focuses on "small and refined", focusing on physical training, body building, yoga and other projects, or focusing on personal customized meticulous, optimized and personalized services; the venue is small in scale, with low investment cost, and generally consists of several coaches with strong comprehensive ability of guidance and management. Under the pressure of large-scale traditional gymnasiums, fitness studios can not only survive in the fierce competition of Liuzhou fitness market, but also develop into a new force that can not be ignored, which effectively fills the gap in the supply of large-scale clubs. Even in the downtown area, they compete and cooperate with comprehensive gymnasiums to attract consumers with different needs and form complementary advantages pattern ${ }^{[3]}$.

\subsection{Supply side analysis}

\subsubsection{Club management status}

Table 1. Liuzhou gym and fitness studio questionnaire.

\begin{tabular}{|l|c|c|c|c|c|}
\hline \multicolumn{1}{|c|}{ Gym Name } & $\begin{array}{c}\text { Area } \\
\left(\mathrm{m}^{2}\right)\end{array}$ & $\begin{array}{c}\text { Club } \\
\text { Member }\end{array}$ & $\begin{array}{c}\text { Coach (man } \\
/ \text { woman) }\end{array}$ & $\begin{array}{c}\text { Charge } \\
\text { Yuan / year }\end{array}$ & Service Items \\
\hline 1 Sanqiang & 1800 & 1200 & $10(7 / 3)$ & 1500 & Fitness, swimming, leisure catering \\
\hline 2Helen & 2800 & 1500 & $12(8 / 4)$ & 1500 & Fitness, dance, nutrition, health care \\
\hline 3King Power & 2000 & 1500 & $11(8 / 3)$ & 1700 & Fitness, dance, aerobics \\
\hline 4Hui Sport & 2000 & 1200 & $11(8 / 3)$ & 1500 & Fitness, consultation, aerobics \\
\hline 5Focus & 2500 & 1500 & $12(8 / 4)$ & 1800 & Fitness, cosmetology, Yoga \\
\hline Fitness Studio & & & & Yuan / time & \\
\hline 6Energy7 & 400 & 300 & $5(3 / 2)$ & 200 & TRX, body building, nutritious meal \\
\hline
\end{tabular}




\begin{tabular}{|l|c|c|c|c|c|}
\hline 7Qing Rui & 200 & 200 & $4(3 / 1)$ & 240 & $\begin{array}{l}\text { Lose weight, gain muscle, body } \\
\text { shape }\end{array}$ \\
\hline 8Fighting & 350 & 200 & $3(2 / 1)$ & 240 & $\begin{array}{l}\text { Lose weight, gain muscle, body } \\
\text { shape }\end{array}$ \\
\hline 9Hongdou Yoga & 200 & 300 & $6(0 / 6)$ & 2500 Yuan / year & Yoga, exercise, physique lesson \\
\hline 10Liuling Yoga & 200 & 350 & $6(0 / 6)$ & 2500 Yuan / year & Yoga, exercise, physique lesson \\
\hline
\end{tabular}

Under the influence of citizens' diversified demand for health and leisure life, the service supply of large-scale fitness clubs has expanded from traditional fitness guidance services to new fields such as nutrition and health care, body rehabilitation, leisure catering and health consultation, forming a diversified supply based on fitness guidance services (see Table 1). Personalized and diversified consumer demand has intensified the supply side segmentation of the fitness market. The fitness studio aims at yoga and aerobics recovered by women and pregnant women, as well as weight-loss, body-building, shaping body, exercise class, rehabilitation and other projects for obese and high-end consumers, and constantly meets the personalized and high-quality fitness needs of special groups. Sanqiang gym with a 24-year history is the representative of mass consumption; Helen and King Power are the rising stars of fashion fitness, facing middle and high-end consumption; Focus is the emerging representatives of high-end consumption; Hui Sport is the emerging representatives of mass consumption (see Table 1). The traditional gym has a large area, large investment, many members, more than 10 full-time coaches, and the annual card fee is about 1500. The fitness studio has a small area, few members and 3-6 fixed coaches (610 in Table 1). The studio pays attention to service quality and provides differentiated services for consumers, so it is conducive to business startup and survival of itself; Private classes require booking service due to limited space, market price is about 200 yuan / class, and group classes such as yoga and exercise classes generally sell annual or quarterly cards. There are obvious differences in the course settings of different theme studios.

\subsubsection{Basic information of fitness coach}

Table 2. Club coach questionnaire.

\begin{tabular}{|c|c|c|c|c|c|c|c|c|c|c|}
\hline \multirow{2}{*}{ Category } & \multirow{2}{*}{ Total } & \multicolumn{3}{|c|}{ Source } & \multicolumn{3}{c|}{ Education } & \multicolumn{3}{c|}{ Age } \\
\cline { 3 - 11 } & & \multicolumn{2}{|c|}{ Specialty, amateur, other } & \multicolumn{2}{c|}{ Below BA,Bachelor,above BA } & \multicolumn{2}{|c|}{$\leq 22$} & $23-35$ & 236 \\
\hline Man & 47 & 17 & 20 & 10 & 19 & 27 & 1 & 10 & 26 & 11 \\
\hline Woman & 33 & 13 & 14 & 6 & 15 & 17 & 1 & 8 & 16 & 9 \\
\hline Total & 80 & 30 & 34 & 16 & 34 & 44 & 2 & 18 & 42 & 20 \\
\hline Proportion(\%) & 100 & 37.5 & 42.5 & 20 & 42.5 & 55 & 2.5 & 22.5 & 52.5 & 25 \\
\hline
\end{tabular}

According to the survey in Table 2, the proportion of coaches with professional background is not high. Some of them are part-time teachers and students of art colleges, mainly engaged in yoga, exercise, body and other courses. The overall education level of coaches is not high, undergraduate and below are the main force, accounting for $97.5 \%$, and graduate students only account for $2.5 \%$; the coaches are younger, $23-35$ years old is the main body of teaching, accounting for $52.5 \%$, and the part-time coaches of college students are generally under 22 years old, accounting for $22.5 \%$, which is the main source of high school coaches of the club. Therefore, the comprehensive quality of coaches still needs to be improved.

\section{Analysis of the main difficulties facing the fitness market}


With the improvement of the quality of life, people's demand for high quality fitness services is increasing. The lack of self-regulation ability and supervision in the fitness market, and the pursuit of profits by social capital, lead to the rapid and overheated development of the market. In recent years, Liuzhou fitness market has been in a state of "saturation" after rapidly warming up. With the vicious competition within the industry, soaring operating costs, declining profit margins, complaints from customers who have been injured in their rights, and the club's "closing down" and other adverse phenomena occur frequently. Corona virus disease 2019 makes the dangerous fitness industry worse,

\subsection{Analysis of the reasons for the closure of the club}

There are three main types of closed fitness clubs: first, Sanqiang, a 24-year gym witnessed the rise and fall of Liuzhou fitness market and finally closed in 2018. Gym decoration and service basically remain unchanged, which will be out of date for the fashionable fitness industry sooner or later. The cost of rental property continues to soar, the profit space of traditional fitness guidance service is almost squeezed to zero, coupled with the heavy burden of staff salaries and equipment renewal costs, some of them have been in debt operation. Second, the new fashion club represented by Helen Dz, Dance Land and Yin He fitness, etc. In order to pursue market coverage and dominant power, blind expansion fell into excessive competition, overdrawn members' multi-year low-cost prepaid card fees in advance in rent, venue decoration, equipment purchase and sales business, service quality decline, resulting in the loss of customers in the second year. The third is the fund problem Club represented by Li Wan and Zuo You fitness, which has the most far-reaching harm to the whole industry, in order to pursue "fast money", encircle money before opening, deviate from the nature of sports, default employees' wages, overdraft members' prepayments, rent and property costs, etc. Only when the citizens fall in love with sports, can the sustainable development of fitness industry be formed. "Cheating money" and the absence of poor service and market supervision have become the main manifestations of deviating from the essence of sports and entering the abnormal development. The lack of supply side credit in some markets will lead to the shadow of consumer psychology, which will be the biggest hidden crisis in the whole fitness industry.

Table 3. Questionnaire on the reasons for the club's closure

\begin{tabular}{|c|c|c|c|}
\hline Gym Name & Number & $\begin{array}{l}\text { Operating } \\
\text { age (year) }\end{array}$ & Main causes of failure \\
\hline 1San Qiang & 1500 & 24 & $\begin{array}{l}\text { High rent property, no change in service items and team, loss of } \\
\text { customers, obsolete equipment. }\end{array}$ \\
\hline 2Dance Land & 1000 & 0.5 & $\begin{array}{c}\text { Rent arrears, low price of multi-year cards, broken capital chain, } \\
\text { unchanged service }\end{array}$ \\
\hline 3Li Wan & 1000 & Unopened & $\begin{array}{l}\text { Start up disadvantage, encircle money, default employee salary, } \\
\text { member prepaid card fee, rental property fee }\end{array}$ \\
\hline 4Car Ter & 1200 & 1 & $\begin{array}{l}\text { Rent arrears, Loss of customers, decline of service quality, poor } \\
\text { management }\end{array}$ \\
\hline 5Helen Dz & 600 & 0.5 & $\begin{array}{l}\text { Overdraft of prepaid card fee, change of owners for several times in } \\
\text { the store, decline of service quality and loss of customers }\end{array}$ \\
\hline 6Zuo You & 1200 & 0.5 & $\begin{array}{c}\text { Misappropriation of advance payment, broken capital chain, arrears } \\
\text { of employees' wages, rent and property costs }\end{array}$ \\
\hline 7 Yin $\mathrm{He}$ & 2000 & 1.5 & $\begin{array}{c}\text { Blind expansion of members, overdraft of cheap prepaid cards, } \\
\text { decline in service quality and poor management }\end{array}$ \\
\hline
\end{tabular}

\subsection{Analysis of problems in market supply}

Traditional large-scale gymnasiums such as Helen and Bund joined in the excessive competition, blindly expanded their branches, and absorbed customers with low price 
multi-year cards. The supply of assimilative environmental equipment and curriculum services has become an invalid supply, resulting in the loss of customers who renew their cards. Fitness studio is committed to creating characteristic projects to meet the diversified needs of consumers, developing new market areas and obtaining living space. Such as TRX resistance training, Zumba, Pilates and other courses are favored by fashion consumers to form a high-quality and effective supply. Therefore, the fitness studio has become a useful supplement to the fitness market. There is a lack of effective communication between clubs, price and service cannot form differentiated competition, excellent coaches are fixed, the running field is not smooth, resources cannot be shared, and the long-term interests of the industry are damaged. The competition for talents in the fitness industry is intensified, the proportion of professional background in sports colleges and universities of fitness coaches is low, and the overall quality needs to be improved.

\subsection{The impact of Corona Virus Disease 2019}

The sudden outbreak of COVID-19 has brought a great blow to the fitness and leisure industry. During the period of COVID-19 prevention and control, the state banned all public gathering activities, which made the weak fitness market worse. It was impossible to open a gym before the epidemic was completely controlled. Rent, property, employee salary, equipment maintenance and other costs are unbearable for many clubs. If there is no other way to carry out business, it is a matter of time to close down. Remote online network teaching mode has become the main business form of clubs in special period. For example, a large number of network teaching software such as zoom, Tencent conference, Rain classroom and so on came into being. Through the network platform, one-to-one and oneto-many fitness service guidance can be carried out, and fitness activities can be completed at home, avoiding the gathering of personnel in the venues. At present, it has been used by many fitness studios in private education, but the use of equipment is relatively limited. The large-scale gymnasium uses private teaching in the gymnasium, and it is generally not recommended to carry out online teaching at home, because the club cannot monitor the coaches to get commissions. If there is a service platform to monitor the coach's online teaching services and cost exchanges, the club will be able to get the same income and survive in the outfield, and pass through the difficult period, which can also develop into the consumption mode of some special groups in the house that are not convenient to come to the gym, and the sudden epidemic will expand the demand for online teaching consumption.

\section{Development strategy of "Internet +" fitness alliance service platform}

\subsection{Basic conditions and functions}

Behind the crisis of the fitness market, it also reflects the demand for win-win cooperation and diversified and personalized consumption demand, strengthens the structural reform of supply side of fitness market, stimulates the innovation of the club, and uses Internet technology as a new power engine, and builds the "Internet +" Fitness Club Alliance service platform, and establishes a fitness club alliance to achieve resource sharing and break different products. Brand sales price barriers, reduce operating costs, realize the transformation and upgrading of fitness industry, and effectively transform the crisis into development opportunities. The operation mode is shown in Figure 1: Under the guidance 
and supervision of the government administration and the alliance, the club, platform and members form a mutual two-way information barrier free exchange.

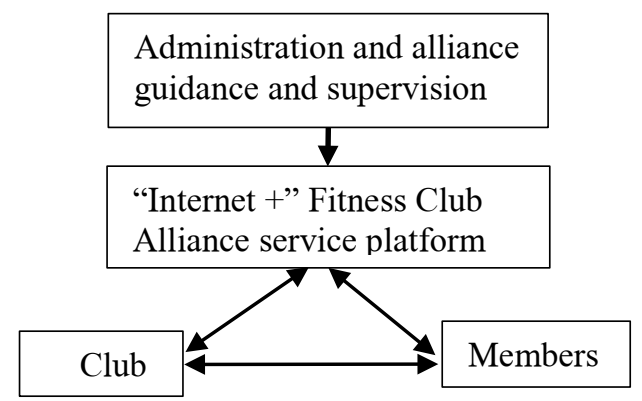

Fig. 1. Service platform information exchange structure chart.

The biggest value of the alliance service platform lies in the sharing of resources among information, manpower and customers. The construction conditions of the service platform are firstly the establishment of fitness alliance in the industry; secondly, the wide application of Internet in clubs; and the monitoring and guidance of government departments on information, services and funds. The alliance service platform can undertake sales, training, advertising and other disconnected business from the club, so that clubs can focus on providing quality services, and achieve information exchange and resource sharing among the alliance, clubs and members, so as to save operating costs (Figure 1).

\subsection{Design and implementation}

The "Internet + " Fitness Club Alliance service platform is a network data exchange platform based on the parallel processing and cross switch architecture. The platform has parallel computing and large throughput. The platform adopts a unified data standard and standardizes the relevant data of the fitness club, which is conducive to the docking of the information system of each fitness club.At the same time, the relevant database, system and other relevant interfaces of different levels are reserved to facilitate the future docking with different systems. At the same time, the relevant database, system and other relevant interfaces of different levels are reserved to facilitate the future docking with different systems. The service platform can also support docking with mobile devices and provide data exchange, so that users can upload fitness data anywhere. The platform integrates the latest fitness data algorithm to provide the best fitness resource scheduling for users and clubs.

The implementation process is as follows: the club voluntarily joins in, through the service platform to sell the alliance card ("Fitness Alliance card") to realize the consumption of one card within the alliance, or to sell the membership card of any joined club, and members can purchase the card freely at the platform service terminal. Members can go to any venue for consumption with the "Fitness Alliance card", and the actual cost can be deducted through the platform price conversion to break the price barriers between clubs and realize free trade. Clubs no longer consume resources to sell and rob members, but rely on improving service quality to attract free flowing members. The diversified needs of members are met without worrying about the failure of a club. Coaches can also flow freely to achieve the innovative development of the whole fitness industry. 


\section{Development strategy}

We will strengthen the construction of club culture, build old brand stores, enhance the sense of belonging of members, create a good atmosphere for fitness, and lay a good foundation for the establishment of fitness alliance. Constantly integrate new technology and advanced management to enhance the comprehensive strength of the club, strengthen the self governance ability of the alliance, and improve and innovate the service platform functions. Strengthen the exchange and sharing of information and resources of each club, reduce operating costs and improve the overall service quality level.

We will strengthen the supply side reform of fitness market, reduce the ineffective supply of homogenized fitness services, increase high-quality and effective supply, guide each club to play its own advantages to carry out differentiated competition, constantly meet the diversified high-quality market demand, and promote the transformation and upgrading of traditional fitness industry. We should explore the structural changes in demand side, and strive to guide and develop the demand for fitness market. The industry will share resources such as information, coaches and customers through the "Internet +" Fitness Club Alliance service platform, and promote healthy and sustainable development of the fitness market.

The open fund project of Hubei leisure sports development research center supported "Research on Guangxi traditional sports consumption" (2019y008); 2018 Guangxi Higher Education Undergraduate Teaching Reform Project (2018JGB176).

\section{References}

1. Ge LUO,Shijun XU, Hai HUANG. Theory Discussion on the Development of “ Internet+ " Liuzhou Gym Industry[J].Sport Science and Technology,2018,39(06):91-93.

2. Funa DU. "Internet Plus" New Engine of China's Economic Development[J]. Seeking Knowledge, 2016(08):56-58.

3. Shijun XU, Zhili PENG, Xiaopeng DONG. Research on the Value of Sports Organizations of Minority Villages[J]. Bulletin of Sport Science \& Technology,2018,26(10):32-33+39.

4. Chai Kai. The Design and Implementation of a Network-Coding Based Simulation Platform for Switches[D].University of Science and Technology of China,2011

5. Chai Kai, Yinlong XU, Xiaobin LIN. Design and Implementation of Network Coding Based Switching System Simulation Platform[J].Computer Applications and Software, 2012,29(02): 22-26. 